\title{
CALCIUM NITRATE AND AMMONIUM NITRATE LIMESTONE AS SOURCES OF NITROGEN FOR OATS AND BARLEY
}

\author{
Pentti Hänninen \\ Agricultural Research Centre, Central Finland Agricultural Experiment Station \\ Armi KaILA \\ University of Helsinki, Department of Agricultural Chemistry
}

Received April 24, 1961

The experiments, the results of which are recorded in the present paper, have been carried out in order to test several observations made in summer 1958. According to these, spring cereals fertilized with the Finnish ammonium nitrate limestone, "Oulunsalpietari", seemed to be retarded in maturing as compared to the cereal stands treated with calcium nitrate. If these observations made in practice were valid, it could be supposed that there would be differences also in the effect of these fertilizers on the yields and nitrogen uptake by the plants.

"Oulunsalpietari» contains 25 per cent nitrogen as ammonium nitrate and about 26 per cent dolomite which makes its magnesium content about 3 per cent. The manufacture of this product was started in 1952, and now it is the most widely used nitrogen fertilizer in our country. Since 1953 its effect has been studied in numerous field trials. SALONEN (1) has published results of experiments from the years 1953-1956. In different groups of trials with spring cereals the effect of "Oulunsalpietari" ranged from 43 to 144 per cent of the effect of calcium nitrate. The average in 62 trials was 88 per cent. Owing to the large variation no significant difference could be demonstrated.

The present authors were fully aware of the fact that this kind of problem must be studied using a method in which the experimental errors may be minimized. One of these is the split-plot technique which allows the testing of even small differences between the treatments. This technique was employed in the field trials carried out in the summers of 1959 and 1960 in order to compare the effects of calcium nitrate and ammonium nitrate limestone (Oulunsalpietari) on oats and, in one case, on barley. The development of the plants and their uptake of nitrogen were continuously followed during the growing period. 
In 12 field trials the effects of calcium nitrate and ammonium nitrate limestone were compared as surface dressing on oats. In one trial barley was used as the experimental crop. The amounts of nitrogen applied as these two fertilizers were 0,25 , and $50 \mathrm{~kg} / \mathrm{ha}$ in 1959 , in 1960 in some of the trials also 75 and $100 \mathrm{~kg} / \mathrm{ha}$ were used in order to get a more distinct nitrogen effect.

Since it could be supposed that the distribution of the fertilizers may have some influence on their effect, in 3 trials they were applied either as a surface dressing or worked in. The application of nitrogen was $50 \mathrm{~kg} / \mathrm{ha}$ in all these experiments.

The total area of an experimental plot was $6 \mathrm{~m} \times 10 \mathrm{~m}=60 \mathrm{~m}^{2}$. One half of each plot was treated with calcium nitrate, the other half with ammonium nitrate limestone (Oulunsalpietari). As a basal dressing $200 \mathrm{~kg} / \mathrm{ha}$ of superphosphate and $100 \mathrm{~kg} / \mathrm{ha}$ of $50 \%$ potash fertilizer was worked in before sowing. The treatments were in randomized blocks replicated four times.

In order to be able to get plant samples during the growing period without disturbing the stand to be harvested, an area of $0.4 \mathrm{~m}$ breadth was reserved for this purpose in each half of the plots. Plant samples were collected every fourteen days. Each time 20 plants were taken from one plot.

The plants were air dried, weighed, and analyzed for total nitrogen by the usual Kjeldahl procedure.

The field trials were carried out in five places: in Central Finland (Laukaa), on the southern coast (Viikki), in east Finland (Tohmajärvi), in southwest Finland (Paimio), and in south Finland (Leteensuo). The list of the trials with some information is the following:

\begin{tabular}{|c|c|c|c|c|}
\hline Trial & Place & Kind of soil & $\mathrm{pH}$ of soil & Year \\
\hline K 1 & Laukaa & silt & 6.2 & 1959 \\
\hline K 2 & , & , & 5.8 & , \\
\hline K 3 & , & 3 & 6.2 & , \\
\hline K 4 & s & , & 5.8 & , \\
\hline K 5 & s & , & 5.9 & 1960 \\
\hline K 6 & , & , & 5.9 & 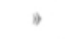 \\
\hline V 1 & Viikki & silt clay & 5.2 & 1959 \\
\hline V 2 & , & finesand clay & 5.7 & 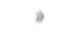 \\
\hline V 3 & , & " & 5.7 & 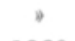 \\
\hline V 4 & 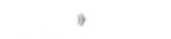 & silt clay & 5.2 & 1960 \\
\hline T 1 & Tohmajärvi & humus soil & 5.6 & 1959 \\
\hline T 2 & , & , & 5.7 & 1960 \\
\hline P 1 & Paimio & very heavy clay & 5.5 & 1959 \\
\hline P 2 & , & " & 5.5 & 1960 \\
\hline L 1 & Leteensuo & heavy silty clay & 5.4 & 1959 \\
\hline L 2 & i & , & 5.4 & 1960 \\
\hline
\end{tabular}

The meteorological conditions were different in these two years and also in the various places. Summer 1959 was extremely dry in south and southwest Finland, in the eastern parts of the country the weather conditions were more favourable. In 1960 the summer was rainy in south and southwest Finland, in Central Finland, on the other hand, the growing seasons were favourable.

\section{Results}

In 1959 the grain yields of oats showed a distinct response to nitrogen fertilizers in most of the trials (Table 1). Between the yields obtained when equal amounts of nitrogen as calcium nitrate or ammonium nitrate limestone were applied, no statistically significant difference at the 5 per cent level could be detected. There was, however, some tendency to a slight superiority of calcium nitrate. If the average 
Table 1. Grain yields of oats in $1959, \mathrm{~kg} / \mathrm{ha}$

\begin{tabular}{|c|c|c|c|c|c|c|}
\hline \multirow[b]{2}{*}{ Trial } & \multirow[b]{2}{*}{ No $\mathrm{N}$} & \multicolumn{2}{|c|}{$\mathrm{N} 25 \mathrm{~kg} / \mathrm{ha}$} & \multicolumn{2}{|c|}{$\mathrm{N} 50 \mathrm{~kg} / \mathrm{ha}$} & \multirow[b]{2}{*}{ LSD $5 \%$} \\
\hline & & $\mathrm{Ca}\left(\mathrm{NO}_{3}\right)_{2}$ & $\mathrm{NH}_{4} \mathrm{NO}_{3}$ & $\mathrm{Ca}\left(\mathrm{NO}_{3}\right)_{2}$ & $\mathrm{NH}_{4} \mathrm{NO}_{3}$ & \\
\hline K 1 & 1090 & 1510 & 1420 & 1700 & 1670 & 160 \\
\hline K 2 & 1160 & 1480 & 1550 & 1660 & 1640 & 250 \\
\hline V 1 & 2890 & 3290 & 3100 & 3410 & 3390 & 460 \\
\hline V 2 & 3860 & 4200 & 4050 & 4190 & 4150 & 240 \\
\hline V 3 & 3150 & 3120 & 3100 & 3100 & 3050 & 340 \\
\hline T 1 & 700 & 1830 & 1650 & 2710 & 2510 & 320 \\
\hline P 1 & 1850 & 2320 & 2210 & 2570 & 2510 & 350 \\
\hline L 1 & 970 & 1340 & 1220 & 1480 & 1510 & 290 \\
\hline
\end{tabular}

increases in yield brought about by these fertilizers are calculated, it is found that the increase produced by $25 \mathrm{~kg} / \mathrm{ha}$ of $\mathrm{N}$ as ammonium nitrate was $77 \%$ of that produced by the same amount of $\mathrm{N}$ in calcium nitrate. The corresponding percentage for the higher amount was 92 .

Table 2. Straw yields of oats in $1959, \mathrm{~kg} / \mathrm{ha}$

\begin{tabular}{|c|c|c|c|c|c|c|}
\hline \multirow[b]{2}{*}{ Trial } & \multirow[b]{2}{*}{ No $\mathrm{N}$} & \multicolumn{2}{|c|}{$\mathrm{N} 25 \mathrm{~kg} / \mathrm{ha}$} & \multicolumn{2}{|c|}{ N $50 \mathrm{~kg} / \mathrm{ha}$} & \multirow[b]{2}{*}{ LSD $5 \%$} \\
\hline & & $\mathrm{Ca}\left(\mathrm{NO}_{3}\right)_{2}$ & $\mathrm{NH}_{4} \mathrm{NO}_{3}$ & $\mathrm{Ca}\left(\mathrm{NO}_{3}\right)_{2}$ & $\mathrm{NH}_{4} \mathrm{NO}_{3}$ & \\
\hline K 1 & 1190 & 1880 & 1760 & 2470 & 2270 & 170 \\
\hline K 2 & 2090 & 3070 & 2720 & 4020 & 3420 & 580 \\
\hline V 1 & 2760 & 3090 & 3060 & 3340 & 3110 & 460 \\
\hline V 2 & 3270 & 3550 & 3410 & 3870 & 3560 & 200 \\
\hline V 3 & 3450 & 3770 & 3690 & 3940 & 3900 & 260 \\
\hline T 1 & 1750 & 2870 & 2650 & 4090 & 3900 & 660 \\
\hline L 1 & 1020 & 1640 & 1460 & 1790 & 1810 & 220 \\
\hline
\end{tabular}

The straw yields of oats in 1959 are reported in Table 2. The response to nitrogen fertilizing is distinct in most of the trials. In trials $\mathrm{K} 1, \mathrm{~K} 2$, and V 2 the straw yields produced by $50 \mathrm{~kg} / \mathrm{ha}$ of $\mathrm{N}$ as calcium nitrate are slightly, but statistically significantly higher than the corresponding yields with ammonium nitrate limestone. The tendency for the superiority of calcium nitrate seems to be even more marked than in connection with the grain yields: $25 \mathrm{~kg} / \mathrm{ha}$ and $50 \mathrm{~kg} / \mathrm{ha}$ of $\mathrm{N}$ as ammonium nitrate limestone have been able to increase the yield only by 74 per cent and 80 per cent, respectively, of the increases which were obtained with the corresponding amount of calcium nitrate.

The nitrogen content of grains and straw in these experiments (Table 3) is, with only a few exceptions, equal in the corresponding treatments with the two fertilizers. In trial L 1 the grains from the calcium nitrate plots are significantly 
Table 3. Nitrogen content of grains and straw of oats in 1959 ( $\mathrm{N}$ per cent of dry matter)

\begin{tabular}{|c|c|c|c|c|c|c|}
\hline \multirow[b]{2}{*}{ Trial } & \multirow[b]{2}{*}{ No $\mathrm{N}$} & \multicolumn{2}{|c|}{$\mathrm{N} 25 \mathrm{~kg} / \mathrm{ha}$} & \multicolumn{2}{|c|}{ N $50 \mathrm{~kg} / \mathrm{ha}$} & \multirow[b]{2}{*}{ LSD $5 \%$} \\
\hline & & $\mathrm{Ca}\left(\mathrm{NO}_{3}\right)_{2}$ & $\mathrm{NH}_{4} \mathrm{NO}_{3}$ & $\mathrm{Ca}\left(\mathrm{NO}_{3}\right)_{2}$ & $\mathrm{NH}_{4} \mathrm{NO}_{3}$ & \\
\hline \multicolumn{7}{|c|}{ Grains } \\
\hline K 1 & 1.96 & 1.98 & 1.98 & 2.15 & 2.08 & 0.08 \\
\hline K 2 & 1.96 & 1.84 & 1.87 & 1.89 & 1.87 & 0.07 \\
\hline V 1 & 1.90 & 2.01 & 1.90 & 2.08 & 2.13 & 0.10 \\
\hline V 2 & 1.81 & 1.93 & 2.03 & 2.07 & 2.09 & 0.32 \\
\hline T 1 & 2.07 & 1.78 & 1.81 & 1.74 & 1.75 & 0.15 \\
\hline L 1 & 1.88 & 2.11 & 1.97 & 2.28 & 2.02 & 0.09 \\
\hline \multicolumn{7}{|c|}{ Straw } \\
\hline V 1 & 0.45 & 0.50 & 0.46 & 0.58 & 0.54 & 0.08 \\
\hline V 2 & 0.54 & 0.51 & 0.54 & 0.58 & 0.58 & 0.14 \\
\hline T 1 & 0.93 & 0.54 & 0.58 & 0.49 & 0.49 & 0.17 \\
\hline
\end{tabular}

richer in nitrogen than those from the ammonium nitrate limestone plots. This is also true for the grains from trial V 1 treated with the lower amounts of nitrogen.

In the following year also higher applications of nitrogen were used in three of the trials. This was done because it could be supposed that the possible difference between the effects of these two fertilizers might be more distinct at the higher application levels.

Table 4. Grain yields of oats in $1960, \mathrm{~kg} / \mathrm{ha}$

\begin{tabular}{|c|c|c|c|c|c|c|c|c|}
\hline \multirow{2}{*}{$\begin{array}{c}\mathrm{N} \text { applied } \\
\mathrm{kg} / \mathrm{ha}\end{array}$} & \multicolumn{2}{|c|}{ K 5} & \multicolumn{2}{|c|}{ V 4} & \multicolumn{2}{|c|}{ T 2} & \multicolumn{2}{|c|}{ P 2} \\
\hline & $\mathrm{Ca}\left(\mathrm{NO}_{3}\right)_{2}$ & $\mathrm{NH}_{4} \mathrm{NO}_{3}$ & $\mathrm{Ca}\left(\mathrm{NO}_{3}\right)_{2}$ & $\mathrm{NH}_{4} \mathrm{NO}_{3}$ & $\mathrm{Ca}\left(\mathrm{NO}_{3}\right)_{2}$ & $\mathrm{NH}_{4} \mathrm{NO}_{3}$ & $\mathrm{Ca}\left(\mathrm{NO}_{3}\right)_{2}$ & $\mathrm{NH}_{4} \mathrm{NO}_{3}$ \\
\hline 0 & \multicolumn{2}{|c|}{2280} & \multicolumn{2}{|c|}{1660} & \multicolumn{2}{|c|}{840} & \multicolumn{2}{|c|}{3400} \\
\hline 25 & 2760 & 2740 & - & - & 2060 & 1820 & - & - \\
\hline 50 & 3290 & 3410 & 1800 & 1760 & 2630 & 2620 & 3950 & 3610 \\
\hline 75 & 3400 & 3430 & 1740 & 1760 & - & - & - & - \\
\hline 100 & 3130 & 3020 & 1690 & 1820 & - & - & 3860 & 3930 \\
\hline LSD $5 \%$ & \multicolumn{2}{|c|}{220} & \multicolumn{2}{|c|}{470} & \multicolumn{2}{|c|}{990} & \multicolumn{2}{|c|}{520} \\
\hline
\end{tabular}

The data in Table 4 show, however, that, as to the grains, even at the higher levels the difference between the effect of these two fertilizers was negligible. The same holds true also for the straw yields reported in Table 5.

The nitrogen content of grains and straw and the amount of nitrogen in the yield harvested in trial K 5 (Table 6) reveal a regular increase with the increasing rate of nitrogen dressing. Yet, the differences between the corresponding values for the treatments with calcium nitrate and ammonium nitrate limestone are mostly lower than the least significant difference at the five per cent level. Only at the 
Table 5. Straw yields of oats in $1960, \mathrm{~kg} / \mathrm{ha}$

\begin{tabular}{|c|c|c|c|c|c|c|}
\hline \multirow{2}{*}{$\begin{array}{c}\mathrm{N} \text { applied } \\
\mathrm{kg} / \mathrm{ha}\end{array}$} & \multicolumn{2}{|c|}{ K 5} & \multicolumn{2}{|c|}{ V 4} & \multicolumn{2}{|c|}{ T 2} \\
\hline & $\mathrm{Ca}\left(\mathrm{NO}_{3}\right)_{2}$ & $\mathrm{NH}_{4} \mathrm{NO}_{3}$ & $\mathrm{Ca}\left(\mathrm{NO}_{3}\right)_{2}$ & $\mathrm{NH}_{4} \mathrm{NO}_{3}$ & $\mathrm{Ca}\left(\mathrm{NO}_{3}\right)_{2}$ & $\mathrm{NH}_{4} \mathrm{NO}_{3}$ \\
\hline 0 & \multicolumn{2}{|c|}{3110} & \multicolumn{2}{|c|}{4530} & \multicolumn{2}{|c|}{2340} \\
\hline 25 & 4430 & 4150 & - & - & 3840 & 3590 \\
\hline 50 & 5290 & 4770 & 5660 & 5490 & 4610 & 4710 \\
\hline 75 & 5510 & 5410 & 5960 & 5670 & - & - \\
\hline 100 & 6120 & 6250 & 6320 & 5680 & - & - \\
\hline LSD $5 \%$ & \multicolumn{2}{|c|}{430} & \multicolumn{2}{|c|}{1070} & \multicolumn{2}{|c|}{1150} \\
\hline
\end{tabular}

highest treatment level could a significant superiority of calcium nitrate in the nitrogen content of grains be found. The same situation may be observed in the nitrogen content of straw from the plots to which $75 \mathrm{~kg} / \mathrm{ha}$ of nitrogen was applied. Also the amount of nitrogen harvested is at this rate of treatment higher when calcium nitrate is used.

No differences between the effect of these fertilizers could be shown by the nitrogen analyses of samples from the other trials.

Table 6. Nitrogen content of grain and straw and the amount of nitrogen in the oats yield of trial $\mathrm{K} 5$.

\begin{tabular}{|c|c|c|c|c|c|c|}
\hline \multirow{2}{*}{$\begin{array}{c}\mathrm{N} \text { applied } \\
\mathrm{kg} / \mathrm{ha}\end{array}$} & \multicolumn{2}{|c|}{$\mathbf{N} \%$ of grain } & \multicolumn{2}{|c|}{$\mathrm{N} \%$ of straw } & \multicolumn{2}{|c|}{$\mathrm{N}$ in yield $\mathrm{kg} / \mathrm{ha}$} \\
\hline & $\mathrm{Ca}\left(\mathrm{NO}_{3}\right)_{2}$ & $\mathrm{NH}_{4} \mathrm{NO}_{3}$ & $\mathrm{Ca}\left(\mathrm{NO}_{3}\right)_{2}$ & $\mathrm{NH}_{4} \mathrm{NO}_{3}$ & $\mathrm{Ca}\left(\mathrm{NO}_{3}\right)_{2}$ & $\mathrm{NH}_{4} \mathrm{NO}_{3}$ \\
\hline 0 & \multicolumn{2}{|c|}{1.67} & \multicolumn{2}{|c|}{0.39} & \multicolumn{2}{|c|}{50} \\
\hline 25 & 1.72 & 1.71 & 0.42 & 0.44 & 66 & 65 \\
\hline 50 & 1.88 & 1.82 & 0.49 & 0.46 & 88 & 84 \\
\hline 75 & 2.09 & 2.01 & 0.60 & 0.50 & 104 & 96 \\
\hline 100 & 2.30 & 2.19 & 0.75 & 0.80 & 118 & 116 \\
\hline LSD $5 \%$ & \multicolumn{2}{|c|}{0.09} & \multicolumn{2}{|c|}{0.10} & \multicolumn{2}{|c|}{8} \\
\hline
\end{tabular}

Table 7. Yield results from trial L 2 in 1960 with barley.

\begin{tabular}{|c|c|c|c|c|c|c|}
\hline & \multirow[t]{2}{*}{ No $\mathrm{N}$} & \multicolumn{2}{|c|}{$\mathrm{N} 50 \mathrm{~kg} / \mathrm{ha}$} & \multicolumn{2}{|c|}{$\mathrm{N} 100 \mathrm{~kg} / \mathrm{ha}$} & \multirow{2}{*}{ LSD $5 \%$} \\
\hline & & $\mathrm{Ca}\left(\mathrm{NO}_{3}\right)_{2}$ & $\mathrm{NH}_{4} \mathrm{NO}_{3}$ & $\mathrm{Ca}\left(\mathrm{NO}_{3}\right)_{2}$ & $\mathrm{NH}_{4} \mathrm{NO}_{3}$ & \\
\hline Grain yield, kg/ha & 3750 & 4880 & 4610 & 5300 & 5080 & 450 \\
\hline Straw & 3180 & 3890 & 3870 & 4190 & 4130 & 510 \\
\hline $\mathrm{N} \%$ in grain & 1.77 & 1.96 & 1.88 & 2.15 & 2.08 & 0.06 \\
\hline $\mathrm{N}$ in grain, $\mathrm{kg} / \mathrm{ha}$ & 66 & 96 & 87 & 114 & 106 & 9 \\
\hline
\end{tabular}


Table 8. Comparing of calcium nitrate and ammonium nitrate limestone as a surface dressing and as worked in

\begin{tabular}{|c|c|c|c|c|c|c|}
\hline \multirow[b]{2}{*}{ Trial } & \multirow[b]{2}{*}{ No $\mathrm{N}$} & \multicolumn{2}{|c|}{ Worked in } & \multicolumn{2}{|c|}{ Surface dressing } & \multirow[b]{2}{*}{ LSD $5 \%$} \\
\hline & & $\mathrm{Ca}\left(\mathrm{NO}_{3}\right)_{2}$ & $\mathrm{NH}_{4} \mathrm{NO}_{3}$ & $\mathrm{Ca}\left(\mathrm{NO}_{3}\right)_{2}$ & $\mathrm{NH}_{4} \mathrm{NO}_{3}$ & \\
\hline \multicolumn{7}{|c|}{ Grain yield $\mathrm{kg} / \mathrm{ha}$} \\
\hline K 3 & 1130 & 1450 & 1480 & 1570 & 1560 & 150 \\
\hline K 4 & 1000 & 1540 & 1550 & 1450 & 1480 & 280 \\
\hline K 6 & 2100 & 3320 & 3150 & 3000 & 3240 & 440 \\
\hline \multicolumn{7}{|c|}{ Straw yield $\mathrm{kg} / \mathrm{ha}$} \\
\hline K 3 & 1660 & 3070 & 3130 & 3250 & 3020 & 340 \\
\hline K 4 & 2080 & 3870 & 3730 & 3970 & 3600 & 800 \\
\hline K 6 & 2810 & 5220 & 5050 & 5200 & 4840 & 530 \\
\hline \multicolumn{7}{|c|}{$\mathrm{N} \%$ in grain } \\
\hline K 3 & 1.99 & 2.24 & 2.24 & 2.22 & 2.18 & 0.11 \\
\hline K 4 & 1.93 & 1.93 & 1.86 & 1.94 & 1.84 & 0.12 \\
\hline K 6 & 1.61 & 1.71 & 1.67 & 1.69 & 1.70 & 0.06 \\
\hline \multicolumn{7}{|c|}{$\mathrm{N} \%$ in straw } \\
\hline K 6 & 0.34 & 0.42 & 0.42 & 0.45 & 0.41 & 0.04 \\
\hline
\end{tabular}

The trial in Leteensuo was in summer 1960 carried out using barley as the experimental crop. The results are recorded in Table 7. Owing to the large variation no statistically significant difference is obtained between the effect of the two fertilizers on the grain or straw yields, although some tendency for the superiority of calcium nitrate may be suspected. In the nitrogen content of the grains, however, a significant difference exists, but it is less distinct in the nitrogen of the grain yield.

In both years some trials were carried out in which the effect of working in of these two fertilizers was studied. The results of these trials are collected in Table 8.

Table 9. Uptake of nitrogen by oats in trial $\mathrm{K} 5, \mathrm{~N}$ mg per 20 plants

\begin{tabular}{|c|c|c|c|c|c|c|c|}
\hline \multicolumn{3}{|r|}{$\mathrm{N}$ applied } & June 6 & June 26 & July 7 & July 22 & August 5 \\
\hline \multicolumn{3}{|c|}{$0 \mathrm{~kg} / \mathrm{ha}$} & 15 & 108 & 130 & 221 & 289 \\
\hline \multirow{2}{*}{\multicolumn{2}{|c|}{$25 \mathrm{~kg} / \mathrm{ha}$}} & as calcium nitrate & 13 & 178 & 215 & 349 & 418 \\
\hline & & " ammonium nitrate & 16 & 178 & 184 & 284 & 340 \\
\hline \multirow[t]{2}{*}{50} & , & calcium nitrate & 17 & 219 & 243 & 437 & 535 \\
\hline & & " ammonium nitrate & 17 & 209 & 276 & 431 & 483 \\
\hline \multirow[t]{2}{*}{75} & s & - calcium nitrate & 18 & 254 & 331 & 533 & 696 \\
\hline & & - ammonium nitrate & 16 & 228 & 335 & 559 & 712 \\
\hline \multirow[t]{2}{*}{100} & , & - calcium nitrate & 16 & 282 & 376 & 678 & 934 \\
\hline & & - ammonium nitrate & 16 & 279 & 335 & 587 & 949 \\
\hline \multicolumn{3}{|c|}{ L. S. D. at $5 \%$} & 6 & 33 & 58 & 123 & 183 \\
\hline
\end{tabular}


There are no differences between these fertilizers according to the grain and straw yields and their nitrogen content. Thus, at least $50 \mathrm{~kg} / \mathrm{ha}$ of nitrogen as calcium nitrate or ammonium nitrate limestone may equally well be applied as a surface dressing or worked in.

According to the observations made in the field in the fairly wet summer of 1958 , the maturing of the cereal stands was retarded in the areas fertilized with ammonium nitrate limestone as compared with those treated with calcium nitrate. In the present trials no difference in the ripening could be detected. Yet, in the latter part of June in southern Finland, and in the beginning of July in Central Finland, there seemed to be some difference in the colour of the stands: calcium nitrate plots were of a darker green than ammonium nitrate limestone plots. Later the differences in the colour disappeared. As an example results of the visual analysis of the stands in trial $\mathrm{K} 2$ are recorded. A colour scale of $0-10$ was used, 10 representing dark intense green, and the green's intensity diminishing down the scale to $0=$ yellow.

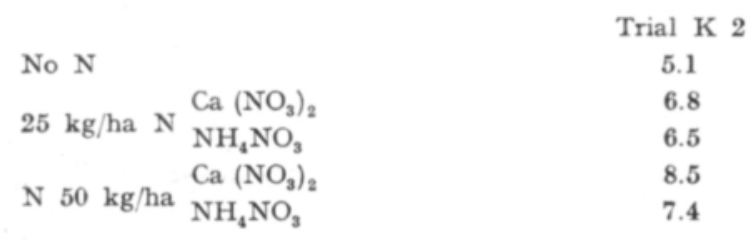

It could be supposed that the darker colour of the calcium nitrate stands would be reflected in the nitrogen content of the plants. Actually, in some cases the percentage of nitrogen in these samples was higher than in those collected from the ammonium nitrate limestone plots. For example on July 9th in trial K 1 the plants treated with the higher amount of calcium nitrate contained 2.80 per cent nitrogen while the plants with the corresponding ammonium nitrate limestone treatment contained only 2.52 per cent nitrogen. Samples collected at the same time from trial $\mathrm{K} 3 \mathrm{had}$ an equal nitrogen content when the fertilizers were worked in, but when applied as a surface dressing, calcium nitrate produced plant material with a nitrogen content of $2.58 \%$, and ammonium nitrate limestone was able to increase the nitrogen content only to $2.29 \%$. In trial $\mathrm{K} 5$ the following nitrogen content for the variously treated plants could be found on the 23 rd of June: In the untreated plants the $\mathrm{N}$ percentage was 2.85 .

$\begin{array}{crcc} & & \text { Calcium nitrate plants } & \text { Ammonium nitrate plants } \\ \mathrm{N} \text { applied } 25 \mathrm{~kg} / \mathrm{ha} & 3.49 \% & 3.55 \% \\ \text {, } 50 & 3.97 \% & 3.90 \% \\ \text {, } & 75, & 4.60 \% & 4.42 \% \\ \text {, } 100 & 5.17 \% & 4.91 \%\end{array}$

In spite of the fairly large variation between the replicates, a statistically significant difference at the 5 per cent level exists in the nitrogen content of the plants treated with $100 \mathrm{~kg} / \mathrm{ha}$ of $\mathrm{N}$.

The large variation in the nitrogen content of the samples from various replicates may be understood on the basis of the theory presented by SPECHT (2) of 
the variation control mechanism. According to this theory, the variation rate between the nutrient content of plants in the same stand has a maximum within the range of the luxury consumption of the nutrients in question. It is likely that in most of the present trials the nitrogen supply was not only above the minimum but also above the "poverty adjustment" range.

Owing to the fairly large variation in the nitrogen content and weight of plants from the replicate plots, only occasionally a significant difference could be detected in the amounts of nitrogen in the 20 plants regularly sampled from the corresponding halves of the plots treated with these two fertilizers. In the cases where a difference existed, calcium nitrate always gave the higher result. As an example of these studies the analyses for trial K 5 are reported in Table 9.

The recovery of fertilizer nitrogen appears to be quite distinct since the sampling at June 26. Yet, the values obtained for the treatments with equal amounts of nitrogen in these two fertilizers do not significantly differ from each other in any case in this trial.

\section{Discussion}

Since the last century the problem of the value of ammonium nitrogen and nitrate nitrogen as the nutrient source of plants has been studied and discussed. Owing to the fact that in these comparisons the effect of the anion of the ammonium salt and the cation of the nitrate also play their role, it has not been easy to find a clear answer to this question. Even if the plants preferably would take up the nitrate ions, in most soils the rapid nitrification will convert ammonium ions to this form, and then only the secondary effects connected with the process will account for the possible differences.

When such fertilizers as ammonium nitrate limestone and calcium nitrate are compared the differences in their effects cannot be very high, since the former has one half of its nitrogen as nitrate. This is likely to be enough to give a start equal to that allowed by calcium nitrate. Later on, the ammonium nitrogen is already converted to nitrate. Only in soils which are able to fix considerable amounts of ammonium ions, this process may be retarded.

In spite of the fact that in the present trials the split plot technique was employed, the variation was so large that only in some cases a statistically significant difference between the effects of these fertilizers could be demonstrated. Then it always indicated the superiority of calcium nitrate. The fairly regular tendency to higher yields and nitrogen content of grains and straw in the calcium nitrate plots of most trials gives support to the few significant results obtained.

In Sweden the field trials show that ammonium nitrate limestone is equal to calcium nitrate as a source of nitrogen to ley, potato, and oats, and also to other crops provided the fertilizer is worked in (Svanberg 1961, unpublished). For barley and wheat, however, calcium nitrate is considered to be the better fertilizer. In the present trial with barley, no significant difference could be shown in the yields produced by these two fertilizers. Only the nitrogen content of the grains produced by calcium nitrate was somewhat higher than those from the 
ammonium nitrate iimestone plots. In this respect, however, the use of ammonium nitrate limestone may be more suitable, since the aim in the cultivation of barley is often the production of grains not too high in nitrogen. It should be noted that the nitrogen content of the grains of oats in the Leteensuo trial of 1959 was also higher in the plots treated with calcium nitrate.

In this kind of trial weather conditions play an important role. Summer 1959 was very dry and warm in the southern parts of the country, the following summer, on the other hand, was fairly wet. In the central parts of the country the summers were more favourable, the latter being even better than the former, since enough rain fell in May and June. It may be assumed that in a very cold and wet growing period the results could have been different from those obtained in the present trials.

In every case, on the basis of the results reported in this paper, the differences in the effect of calcium nitrate and ammonium nitrate limestone on oats are so low that these fertilizers may be considered equally effective as the nitrogen source for this crop.

\section{$S u m m$ ar $y$}

Calcium nitrate and ammonium nitrate limestone ("Oulunsalpietari») were compared as the nitrogen fertilizer for oats in 15 field trials and for barley in one trial. The trials were carried out in summers 1959 and 1960 in various places in Finland. The split plot technique was employed in order to reduce the variation as much as possible. In 1959 the amounts of nitrogen applied as these two fertilizers to the corresponding halves of the plots were 25 and $50 \mathrm{~kg} / \mathrm{ha}$. In 1960 also higher applications were used: 75 and $100 \mathrm{~kg} /$ ha of $\mathrm{N}$. In three trials these fertilizers were compared both as a surface dressing and worked in.

Visual observations suggested about 5-6 weeks after sowing a darker green colour in the stands treated with calcium nitrate as compared with the other half treated with ammonium nitrate limestone. These differences later disappeared. In some trials a higher nitrogen content of the plants from the calcium nitrate stands could be demonstrated during this period.

The uptake of nitrogen by plants was regularly followed throughout the growing period. Owing to the large variation, usually, no statistically significant difference between the effect of the fertilizers could be detected. In a few cases the superiority of calcium nitrate could be demonstrated.

No differences in the ripening could be found.

In most trials there was a fairly regular tendency to higher yields and higher nitrogen content in the grain and straw produced by calcium nitrate. Yet, only in a few cases were the differences statistically significant at the five per cent level. Thus, it was concluded that on the basis of the results of these trials ammonium nitrate limestone and calcium nitrate may be considered practically equal as nitrogen fertilizers for oats.

There was no difference in the yields of barley produced by these two fertilizers, but the nitrogen content of grains was significantly lower with ammonium 
nitrate limestone than with calcium nitrate. This may be worth further study in connection with the production of malting barley.

Acknowledgement. The authors wish to express their gratitude to Norsk Hydro-Elektrisk Kvaelstofaktieselskab, Oslo, for providing funds for the field trials.

\author{
R E F E R E N C E S
}

(1) SALONEN, M. 1958. Erilaisten typpilannoitteiden vaikutuksen vertailua. Kenttäkokeiden tuloksia vuosilta 1952-56. Referat: Vergleich der Wirkung verschiedener Stickstoffdüngemittel Staatl. Landw. Versuchstät. Veröff. Nr. 169, Helsinki, 24 S.

(2) Sреснт, A. W. 1960. Evidence for and some implications of a variation-control mechanism in plant composition. Soil Sci. 89: 83-91.

SELOST U S :

KALKKISALPIETARI JA OULUNSALPIETARI KAURAN JA OHRAN TYPPILANNOITTEINA

Pentti Hänninen

Maatalouden tutkimuskeskus, Keski-Suomen koeasema, Kuusa

ARMi KAILA

Yliopiston maanviljelyskemian laitos, Helsinki

Kesällä 1959 ja 1960 suoritettiin eri puolilla Suomea osaruutumenetelmää käyttäen kenttäkokeita, joissa verrattiin kalkkisalpietaria ja oulunsalpietaria kauran typpilannoitteena sekä myös yhdessã kokeessa ohran typen lähteenä.

Silmävaraisten havaintojen mukaan olivat noin $5-6$ viikon ikäiset kalkkisalpietaria saaneet kasvustot tummemman vihreitä kuin vastaavat oulunsalpietarilla lannoitetut. Joissakin kokeissa oli kalkkisalpietariruutujen kasvinäytteiden typen pitoisuus tähän aikaan suurempi kuin vastaavien oulunsalpietaria saaneiden näytteiden. Värierot hävisivät myöhemmin.

Tuleentumisajassa ei voitu havaita mitän eroja.

Typen ottoa seurattiin koko kasvukauden ajan analysoimalla kultakin koeruudulta kahden viikon tai kymmenen päivăn väliajoin otetut kasvinäytteet. Suuren hajonnan takia olivat erot harvoin tilastollisesti merkitsevät, mutta jos eroja voitiin todeta, ne osoittivat kasvien ottaneen enemmän typpeä kalkkisalpietarista kuin oulunsalpietarista.

Jyvä- ja olkisatojen sekä niiden typen pitoisuuden perusteella voitiin vain muutamissa tapauksissa todeta eroa lannoitteiden vaikutuksessa, ja tällöin oli kalkkisalpietari aina parempi typen lähde. Näitten kokeitten perusteella kalkkisalpietari ja oulunsalpietari näyttävät olevan käytännössä jokseenkin tasaveroisia kauran typpilannoitteena.

Koska ohrakokeessa saatiin kummallakin lannoitteella yhtä suuret sadot, mutta oulunsalpietarikoejäsenten jyvien typen pitoisuus oli matalampi kuin vastaavien kalkkisalpietarilla lannoitettujen, lienee syytä tarkistaa, olisiko tällä seikalla merkitystä mallasohran viljelyssä. 